\title{
Solid-Phase Biosorbents for Water Purification from Petroleum Hydrocarbons
}

\author{
Y.A. Leykin, Professor, Doctor of Chemical Sciences ${ }^{1}$, \\ T.A. Cherkasova, Leading Researcher, Candidate of Chemical Sciences ${ }^{1}$, \\ M.A.Aly-Eldine, Researcher, doctoral ${ }^{2}$, \\ M.A. Miziev, Postgraduate Student ${ }^{1}$
}

${ }^{1}$ D. Mendeleyev University of Chemical Technology of Russia

${ }^{2}$ National Institute of Oceanography and Fisheries, Alexandria, Egypt

e-mail: leykinya@mail.ru, tacherpur@yandex.ru, alieldine@mail.ru, magomed.miziev@mail.ru

\author{
Keywords: \\ sorption, \\ biodegradation, \\ immobilized microbial cells, \\ biosystems and kinetics.
}

\begin{abstract}
In the model solution of dodecane investigated sorbents with immobilized microbial cells genus Pseudomonas (K-5-25, A-2) and Rhodococcus (EriA. 2-4m). Sorbents based on non-woven fabrics made of polypropylene fibers (neutral) and the acrylonitrile fibers containing in their structure of the group of primary and secondary amines, as well as on natural material of the mineral from the group of hydrous layered structure. The efficiency of the sorption and biocatalytic contributions to the study of the degree of water purification. Such self-recovering system, combining physico-chemical and biological removal of petroleum hydrocarbons from solutions with low concentrations of trace and can operate in dynamic mode. Moreover, the sorbent performs one of the most important functions of biological systems, providing delivery and accumulation of oil components from the liquid phase, immobilized cells and carry out selfregeneration biosorbent. Analysis of the comparative effectiveness of these processes with the use of a kinetic model of the results obtained on the solid-phase sorbent with immobilized cells and the initial sorbent without cells, allowed us to determine the degree of physical and chemical removal of dodecane from an aqueous emulsion and the degree of biodegradation, as in liquid, and in solid phase sorption material. The most efficient biological system has shown itself on the basis of non-woven material acrylonitrile, allowing up to 8 days to reduce the concentration of dodecane to the level of maximum permissible concentration and below.
\end{abstract}

\section{Introduction}

Application of highly effective sorption technologies for producing high-purity water usually involves pretreatment of water to remove petroleum hydrocarbons (PHCs) that causes loss of sorption activity due to blocking and "poisoning" of active ionic centers of polymeric ion exchangers. One of the most economically efficient means of the removal of spilled oil from either land or sea is the use of sorbents (Walkup et al., 1969). Synthetic sorbents such as polypropylene and polyurethane are the most commonly used commercial sorbents in oil-spill cleanup due to their oleophilic and hydrophobic characteristics (Schatzberg, 1971).

Bio-catalytic methods of water purification from oil hydrocarbons using immobilized oil-oxidizing microorganisms can significantly increase treatment efficiency ( $\mathrm{Li}$ et al., 2005), compared to using the active solid phase support only.

In general, biological treatment of environmental pollutants is preferred over physicochemical as the former is cost effective, efficient and environmentally friendly (Ojo, 2006). 
The method of cell immobilization on carrier materials seems to be promising in the development of the biotechnological method for removing organic pollutants. Since the immobilized cells remain viable for a significant duration, they are considered as a better alternative for the biotreatment of variety of toxic organic pollutants compared to free cells (Bettmann\&Rehm 1984; O'Reilly \& Crawford 1989; Westmeier\&Rehm 1985, 1987; Belfanz\&Rehm 1991; Menke\&Rehm 1992; Kochar\&Kahlon 1995; Lee et al. 1994 and Sahasrabudhe et al. 1988). Such systems can operate under biocatalytic regime of PHCs destruction in dynamic conditions, or create self-regenerating biosorbents for removal of PHCs from solutions with small and trace concentrations (Leykin et al., 2008; 2009). At the same time sorbent performs one of the most important functions of biosystem, ensuring the delivery and accumulation of PHCs components from liquid phase. Immobilized microbial cells perform self-regeneration, ensuring reduction of $\mathrm{PHCs}$ concentration in solid phase of adsorbed material. Therefore, the aims of the present study areobtaining an artificial biosystem with the effective functioning of immobilized cells, determination of the bacterial capacity to biodegrade adsorbed PHCs and determination of the biocatalytic activity after several degradation cycles.

\section{Materials and Methods}

The object of our study was artificial biosystem with immobilized microorganism. Because of mixed cultures carry out more extensive biodegradation of petroleum than pure cultures (Komukai et al., 1996; Foght et al., 1999; Ghazali et al., 2004; Sun et al., 2005; Gerdes et al., 2005; Trindade et al., 2005; Oteyza et al., 2006; Malik and Ahmad, 2012), double strains of Pseudomonas fluorescens and one strain of Rhodococcuserytropolis were immobilized on vermiculite and double types of Nonwoven fibers: based on polypropylene (PP) and acrylonitrile fiber (AN-3), allowing, in comparison, the evaluation of kinetics of catalytic processes and calculation of activation parameter of enzymes immobilized on a solid phase substrate by varying the dose of normalized mineral solution composition (Leykin et al., 2008).These types of organisms are neither pathogenic nor toxic to humans, animals and plants. Nutrition medium for these strains consists of standard solution of a certain ratio of nitrogen, phosphorus, potassium at the level of phosphate $0,051 \mathrm{mmol}$ per $1 \mathrm{~g}$ of biosorbent.

In this paper, the selection of these support materials (Vermiculite, PP and AH-3) to immobilize the three bacterial strains was due to their high sorption characteristics, porosity, chemical and biological stability, hydrophobicity, possibility of reusing and low price. Sorption parameters were determined under static conditions us- ing dodecane emulsion (DD), prepared as described by Leykin et al. (2008) in five replicates for 24 hours reaction time. Final concentration of DD was determined by the difference between the initial and residual concentration of DD in the emulsion.

Cell immobilization activation of the genus Pseudomonas (K-5-25, K-2) and Rhodococcus (EriA. 4M-2) was carried out at the same time. For the preparation of microorganisms suspension, $1 \mathrm{~g}$ of each strain was placed in $1 \mathrm{~L}$ of buffer with a nutrient medium $\left(\mathrm{K}^{+}, \mathrm{Na}^{+}, \mathrm{PO}_{4}{ }^{3-}\right.$, $\mathrm{Cl}^{-}, \mathrm{NH}^{4+}$ ), stirred and then treated by the method described by Leykin et al. (2008). Biomaterial was separated from the liquid phase and washed out three times with $10 \mathrm{ml}$ of potassium phosphate buffer and was ready for degradation of DD. The quantity of immobilized cells was determined by gravimetric method and immobilized cells were subjected to scanning electron microscopy.

Biodegradation experiment set-up: $100 \mathrm{ml}$ of an aqueous emulsion of DD was added to Erlenmeyer flask, after adjusting of $\mathrm{pH}$ to 9,0 using $0,1 \mathrm{~N} \mathrm{NaOH}$, followed by the addition of $0,4 \mathrm{~g}$ of the biosorbent with immobilized cells according to method described by Leykin et al. (2008). After certain time, the liquid phase was separated by decantation of biosorbent and analyzed for content of petroleum hydrocarbons using standard IR spectrometric method.

All analyses of PHCs determinations as well as scanning electron microscopy were done in the Center for CollectiveUse (CCU), D. Mendeleyev University of Chemical Technology of Russia.

Studies on vermiculite: Weighed air-dried biosorbent based on vermiculite $(\mathrm{g}, \mathrm{g})$ was placed in a solution $(\mathrm{V}, \mathrm{L})$ of freshly prepared emulsion of DD with the initial concentration $\mathrm{C}_{0}=100 \mathrm{mg} / \mathrm{L}$, and the system was kept for $1,2,3$, 4, 5 days, which represented one cycle. Afterthat, exhaustedbiosorbent was separated from the liquid phase and transferred to freshly prepared emulsion $\left(\mathrm{C}_{0}=100 \mathrm{mg} / \mathrm{L}\right)$ for the next cycle. Every biosorbent was used for 3 consecutive cycles (360 hours).

The effectiveness of biochemical oxidation process using biosorbentwas evaluated according to the following equation:

$$
V_{s p}=\left(C_{0}-C_{t}\right) \frac{v}{g t},
$$

where $V_{s p}$ - specific rate of bio-destruction of petroleum hydrocarbons (rate of destruction of PHCs by $1 \mathrm{~g}$ of biosorbent in hour, $\left.\mathrm{mg} \cdot \mathrm{g}^{-1} \cdot \mathrm{hr}^{-1}\right) ; C_{0}$ - initial concentration of PHCs $(\mathrm{mg} / \mathrm{L}) ; C_{t}$ - concentration of PHCs $(\mathrm{mg} / \mathrm{L})$ at the time $t(\mathrm{hr}) ; v$ - the volume of liquid phase (L); $g$ the weight of biosorbent $(\mathrm{g})$ and $t-$ the time of biodestruction (hr). 
Contribution of biodegradation (\%) in the process of DD removal by sorbent with immobilized cells was calculated as follows: $\mathrm{C}_{\mathrm{t}}^{\text {destr }}=\left(C_{0}-C_{t}^{\text {sum }}\right)-C_{t}^{\text {sorb. }}(\mathrm{mg} / \mathrm{L})$; $\Delta_{\text {destr. }}=C_{t}^{\text {destr }} /\left(C_{0}-C_{t}^{\text {sum }}\right) \%$, where $C_{0}-$ initial concentration of DD in the emulsion $(\mathrm{mg} / \mathrm{L}) ; C_{t}^{\text {sum }}-\mathrm{DD}$ concentration in the emulsion $(\mathrm{mg} / \mathrm{L})$ after contact with the biosorbent with immobilized cells at a time $t ; C_{t}^{\text {sorb }}-\mathrm{DD}$ concentration in the emulsion $(\mathrm{mg} / \mathrm{ml})$ after contact with sorbent (without cells) at the time $t$; $\Delta_{\text {destr. }}$ - the contribution of biodegradation, in \% (Leykin et al., 2008).

\section{Theory and Calculation}

The process of PHCs removal from aqueous phase by artificial biosystem is determined by double main processes: PHCs adsorption by solid phase, and biocatalytic oxidation of PHCs by immobilized microorganisms. In the case of biodegradation by microorganisms in liquid phase, capacity range is located in the region of relatively high concentrations of PHCs, and the bio-oxidation process acts efficiently only at sufficient PHCs concentrations. In the solid phase, higher adsorption can be achieved by biocatalytic sorbent. This provides an increase rate of biooxidation for immobilized microorganisms according to Michaelis-Menten equation (Dixon and Webb, 1982). Thus, relatively high distribution coefficients of PHCs on specially chosen carriers enable the extension of application range of this method to small and trace concentrations of PHCs from aqueous phase and provide very small residual concentrations.

Using polymer sorbents with different active groups (anion exchangers, cation exchangers and neutral copolymers) as carriers for immobilization allowsto organize and regulate the transportation of not only PHCs, but also ionic biogenic components that are effective in biocatalytic processes. Treated water may contain ions of heavy metals with the concentration of $10^{-2}-10^{-10} \mathrm{M}$ (Cherkasova et al., 1999), that are capable of irreversibly to inhibiting cells enzyme. At the same time ions of mercury (II), silver (I) and arsenic (III) in small concentrations only block the active center of the enzyme's sulfhydryl group. High concentrations of heavy metal ions cause denaturation of protein part of the enzyme, i.e. completele deactivate the enzyme. During the process of enzymatic reaction, when the enzyme is saturated, the reaction rate is likely to depend only on enzyme concentration and not on substrate concentration, i.e. is limited by the number of active immobilized cells.

Combination and synchronization of the double processes in biosorbent enable the realization of important function of biogenic element preconcentration. Kinetic model of results obtained on the artificial biosystem (on solid-phase sorbent with immobilized cells) and on the initial sorbent without immobilized cells was studied to estimate comparative effectiveness of these processes.
Similarity in their diffusion characteristics was presupposed by using the same solid phase.

Earlier it was shown that the adsorption of PHCs on granular sorbents is limited by internal diffusion and is adequately described by the classical model using a series of Patterson's thermal conductivity applied by Boyd and others (Boyd et al, 1947) for diffusion in sphere:

$$
\begin{aligned}
& F_{t}=1-\sum_{n=1}^{\infty} \frac{6}{n^{2} \pi^{2}} \exp \left(-\frac{n^{2} \pi^{2} D_{i n} t}{r^{2}}\right)= \\
& =1-\sum_{n=1}^{\infty} \frac{6}{n^{2} \pi^{2}} \exp \left(-n^{2} \pi^{2} \mathrm{Fo}\right)
\end{aligned}
$$

At the final stage where the values of the Fourier number are high $\left(\mathrm{Fo}=D_{\text {in }} t / r^{2}\right)$ series converges rapidly and the first term of the series for $n=1$ provides sufficient accuracy in logarithmic coordinates $\ln \left(1-F_{t}\right)=f(t)$, starting from $F_{t}>0,5$ :

$$
\ln \left(1-F_{t}\right)=\ln \frac{6}{\pi^{2}}-\frac{\pi^{2} D_{i n} t}{r^{2}} .
$$

For the initial stage at small values of the Fourier number $D_{\text {in }} t / r^{2}$ :

$$
F_{t}=\frac{2 S_{r}}{V_{r}} \sqrt{\frac{D_{i n} t}{\pi}}
$$

where for sphere

$$
S_{r}=4 \pi r^{2} ; V_{r}=\frac{4}{3} \pi r^{3} ; F=\frac{6}{r \sqrt{\pi}} \sqrt{D_{i n} t} .
$$

Znamensky's approximation equation (Znamensky, 1993) gives a good description of internal diffusion at $F_{t}$ $0,01-0,98$, which can be easily solved with respect to $t$ and the dimensionless time Fourier criterion $F_{\mathrm{o}}$ :

$$
-F_{t} \lg \left(1-F_{t}\right)=\frac{\pi^{2}}{2} \mathrm{Fo}=\frac{\pi^{2}}{2} \frac{D_{i n} t}{r^{2}} .
$$

Presentation of the adsorption process in coordinates of logarithmic rate $\lg \left(1-F_{t}\right)=f(t)$ shows that the overel curve as a linear second order splits into double regions, which is typical for internal diffusion (see Fig. 1).

Error calculation $(\delta, \%)$ of internal diffusion coefficients $\left(D_{\text {in }}, \mathrm{cm}^{2}\right)$ from the experimental data is quite acceptable for the calculation assessment and strongly depends on the number of experimental points in the corresponding region: 
- For root dependence $\left(F_{t}<0,5\right)\left(D_{\text {in }}=5,8 \pm 0,3\right) 10^{-9}$, $\delta=5 \%$

- For Znamensky's equation $(7,6 \pm 1,2) 10^{-9}, \delta=16 \%$;

- For logarithmic dependence $\left(F_{t} \geq 0,5\right)(2,6 \pm 0,9) 10^{-9}$, $\delta=31 \%$.

Investigation of the kinetic processes of the removal of PHCs from aqueous phase using artificial biosystem under static conditions allowed us to determine the concentrations of hydrocarbon in the emulsion after contact with the sorbent without cells $\left(C_{t}^{\text {sorb }}, \mathrm{mg} / \mathrm{L}\right)$ and biosorbent $\left(C_{t}^{\text {sum }}, \mathrm{mg} / \mathrm{L}\right)$ during the time $t$. It also allowed us to calculate the degree of removal of PHCs from the aqueous phase by sorbent $\left(F_{t}^{\text {sorb. }}\right)$ and biosorbent $\left(F_{t}^{\text {gsum. }}\right)$. The adsorbed amount was calculated using the following mass balance equation (mg PHCs/1 g sorbent)

$$
q_{t}=\frac{\left(C_{0}-C_{t}\right) V}{g},
$$

where $C_{0}$ - initial concentration of PHCs $(\mathrm{mg} / \mathrm{L}) ; \mathrm{V}-$ the volume of liquid phase $(L) ; C_{t}-$ concentration of PHCs $(\mathrm{mg} / \mathrm{L})$ at the time $t(\mathrm{hr})$ and $g-$ the weight of biosorbent $(g)$.

\section{Result and Discussion}

Table 1 shows the parameters of the DD removal process from emulsion by sorbent and biosorbent based on polypropylene (PP) material.

From a comparison between the degree of sorption process $\left(\mathrm{F}_{\mathrm{t}}\right)$ by sorbent and biosorbent we concluded that, degree of purification process by biosorbent is more effective than the process with sorbent without immobilized cells. Experimental and calculated data of these processes allow us to determine the amount of destructed hydrocarbon at various time intervals, as well as estimate the rate of both processes.

Using the root dependence for approximation of the initial region and logarithmic dependence for the final region allows us to make a good description of the whole kinetic curve as $F_{t}^{\text {calc. }}=f(t)$. To characterize the accuracy of the calculation, the following linear dependence equation used:

$$
F_{t}^{\text {calc. }}=0,002+0,986 F_{t}^{\text {exper. }}\left(r_{\text {corr. }}>0,99\right) \text {. }
$$

Equations for both plots of kinetic dependences (Fig. 1) show high correlation coefficients $r_{\text {corr. }}$

For the initial area 1

$$
\ln \left(1-F_{t}\right)=-0,62 \mathrm{t}-0,034\left(r_{\text {corr. }}=0,98\right) .
$$

For the final area 2

$$
\ln \left(1-F_{t}\right)=-0,01 \mathrm{t}-0,730\left(r_{\text {corr. }}=0,99\right),
$$

which demonstrates the accuracy of the proposed equations with small average error values based on Student's t test $\left(\sigma_{\mathrm{yc}}=0,020\right)$.

Comparison of DD removal processes from emulsion by sorbent and biosorbent based on PP, revealed that the residual concentration of $\mathrm{DD}\left(C_{t}^{\text {sum }}\right)$ in the aqueous phase (Fig. 2) when using biosorbent is lower than its concentration $\left(C_{t}^{\text {sorb. }}\right)$ when using the sorbent without any immobilized cells (10 mg/L instead of $34 \mathrm{mg} / \mathrm{L}$ over 24 hours). The sorption capacity of pure sorbent is $13,75 \mathrm{mg} / \mathrm{g}$, while overall sorption capacity - 19,75 mg/g (Table 1).

The obtained data show that, the limiting internal diffusion mechanism of sorption and equation of internal diffusion enable the kinetics description of the process with sufficiently high accuracy, especially for the final region of the dependence, despite the fact that the process is accompanied by a polarity change of the solid phase due to the formation of the primary layer of PHCs on the sorbent and increase of the affinity towards it.

Assuming that small amounts of the immobilized microorganisms of biosorbent $(30-40 \mathrm{mg} / \mathrm{g}$ ) did not significantly affect the intra-diffusive performance of the support material, we evaluated the contributions of each

\begin{tabular}{|c|c|c|c|c|c|c|c|c|c|}
\hline \multirow[b]{2}{*}{$\mathrm{t}, \mathrm{hr}$} & \multirow[b]{2}{*}{$C_{t}^{\text {sorb }}, \mathrm{mg} / \mathrm{L}$} & \multirow[b]{2}{*}{$C_{t}^{\text {sum }}, \mathrm{mg} / \mathrm{L}$} & \multirow[b]{2}{*}{$F_{t}^{\text {sorb }}$} & \multirow[b]{2}{*}{$F_{t}^{\text {sum }}$} & \multicolumn{2}{|c|}{ contribution } & \multicolumn{3}{|c|}{$q_{t}, \mathrm{mg} / \mathrm{g}$} \\
\hline & & & & & $\begin{array}{l}\text { sorption } \\
\Delta_{\text {sorp. }}\end{array}$ & $\begin{array}{l}\text { destruction, } \\
\Delta_{\text {destr. }}\end{array}$ & sum & sorption & destruction \\
\hline 0,5 & 59 & 34 & 0,34 & 0,62 & 0,55 & 0,45 & 13,75 & 7,50 & 6,25 \\
\hline 1,0 & 48 & 31 & 0,46 & 0,65 & 0,71 & 0,29 & 14,50 & 10,25 & 4,25 \\
\hline 2,0 & 45 & 27 & 0,50 & 0,70 & 0,69 & 0,31 & 15,50 & 10,75 & 4,75 \\
\hline 4,0 & 42 & 16 & 0,53 & 0,82 & 0,60 & 0,40 & 18,25 & 11,00 & 7,25 \\
\hline 6,0 & 40 & 15 & 0,55 & 0,83 & 0,66 & 0,34 & 18,50 & 12,25 & 6,25 \\
\hline 24,0 & 34 & 10 & 0,62 & 0,89 & 0,70 & 0,30 & 19,75 & 13,75 & 6,00 \\
\hline
\end{tabular}

Parameters of the DD removal processes from an emulsion with one normal dose of nutrients

Table 1

by sorbent and biosorbent based on Nonwoven PP $\left(C_{0}=89 \mathrm{mg} / \mathrm{L}, V=0,1 \mathrm{~L}, g=0,4 \mathrm{~g}\right.$, temp: $\left.20-22^{\circ} \mathrm{C}, \mathrm{pH}_{\text {inti. }}=8,9\right)$ 


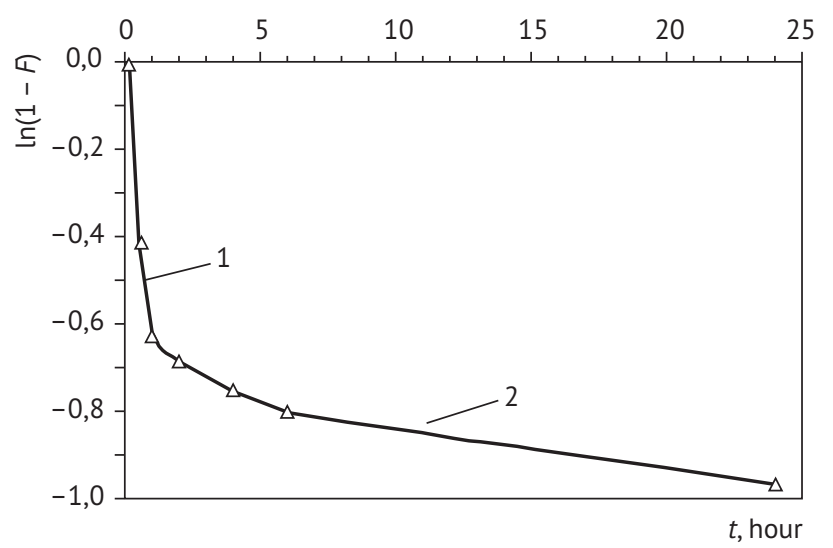

Fig. 1. Dependence $\ln \left(1-F_{t}\right)=f(t)$ for the sorption of $D D$ from emulsion by Nonwoven PP in static conditions $\left(C_{o}=89 \mathrm{mg} / \mathrm{L}, V=0,1 \mathrm{~L}\right.$, $g=0,4 \mathrm{~g}$, temp: $20-22^{\circ} \mathrm{C}, \mathrm{pH}_{\text {init. }}=8,9$ ).

of the processes (sorption and biodegradation) separately $\left(\Delta_{\text {sorb }}, \Delta_{\text {destr }}\right)$. Contribution by pure sorption of DD by biosorbent PP versus time is at the level of $0,55-0,70$, the proportion of biodegradation is equal to $0,30-0,45$ (with an average $35 \%$ ).

The obtained data show that, the limiting internal diffusion mechanism of sorption and equation of internal diffusion enable the kinetics description of the process with sufficiently high accuracy, especially for the final region of the dependence, despite the fact that the process is accompanied by a polarity change of the solid phase due to the formation of the primary layer of PHCs on the sorbent and increase of the affinity towards it.

Assuming that small amounts of the immobilized microorganisms of biosorbent $(30-40 \mathrm{mg} / \mathrm{g})$ did not significantly affect the intra-diffusive performance of the support material, we evaluated the contributions of each of the processes (sorption and biodegradation) separately $\left(\Delta_{\text {sorb }}, \Delta_{\text {destr }}\right)$. Contribution by pure sorption of DD by biosorbent PP versus time is at the level of $0,55-0,70$, the proportion of biodegradation is equal to $0,30-0,45$ (with an average $35 \%$ ).

The possibility of forecasting residual concentration for the process of PHCs removal by biosorbentwas tested using different methods of approximation of kinetic curves. According to the linear relationship $\left(\mathrm{C}_{\mathrm{t}}^{\text {sum }}\right)$ over time $t$ for the initial stage, the forecast is not accurate enough as it reaches $\mathrm{MPC}_{\mathrm{w}}=0,05 \mathrm{mg} / \mathrm{L}$ very fast. According to logarithmic dependence equation for the final stage, the forecast appears to be reliable. For the biosorbentbased on Nonwoven $\mathrm{PP}$, we used the following approximating equation:

$$
\ln \left(1-F_{t}^{\text {sum }}\right)=-1,63-0,023 t\left(r_{\text {corr. }}>0,99\right) .
$$

From this equation, the predicted time to achieve the residual concentration of $0,05 \mathrm{mg} / \mathrm{L}$ of PHCs can be ob-

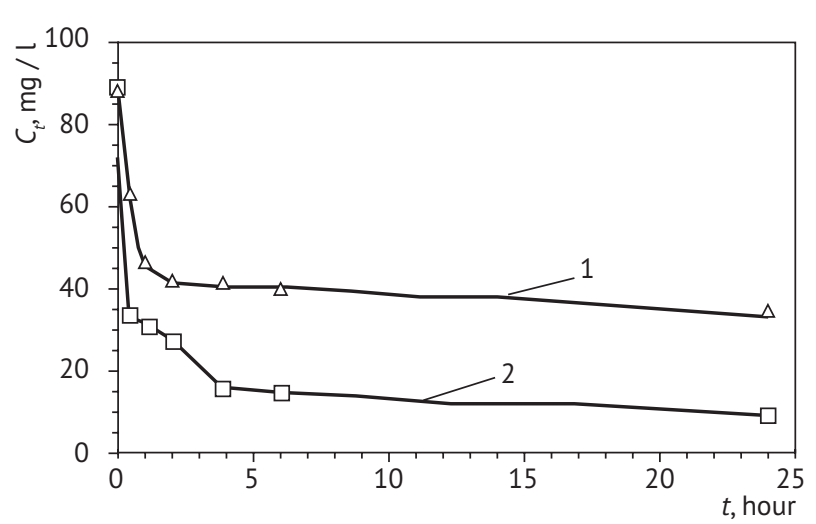

Fig. 2. The change in concentration of DD in the aqueous phase with time for removal processes by sorbent (1) and biosorbent (2) based on Nonwoven PP in static conditions $\left(C_{o}=89 \mathrm{mg} / \mathrm{L}, V=0,1 \mathrm{~L}, g=0,4 \mathrm{~g}\right.$, temp: $\left.20-22^{\circ} \mathrm{C}, \mathrm{pH}_{\text {init. }}=8,9\right)$

tained(10,5 days), while when using pure sorbent of PP for the same time, it reaches concentration that is twice greater $(2,5 \mathrm{mg} / \mathrm{L})$ :

$$
\ln \left(1-F_{t}^{\text {sorb }}\right)=-0,70-0,012 t ;\left(r_{\text {corr. }}=0,95\right) .
$$

Nonwoven material based on PP showed a good ability to retain cells in its structure, as well as the ability to concentrate PHCs from the liquid phase and bio-oxidative destruction of PHCs by active immobilized cells. The experimental data showed that the immobilization of microbial cells, basically, allows us to increase the speed of PHCs removal process twice in comparison with the sorbent itself, as well as reduce the inhibitory effect of heavy metal impurities.

Experimental data obtained by studying the ionic hydrophilic Nonwoven AN-3 material, containing active functional groups of primary and secondary amines, are shown in Table 2.

Dependence of $F_{t}=f(t)$ in logarithmic coordinates for pure sorption process of DD by AN - 3 is represented by a second order curve which splits into double linear sections with high correlation coefficients $\left(r_{\text {corr. }}=0,97\right.$ and 0,96 ), which is characteristic for limitation process by internal diffusion. Using the root dependence for approximation $F_{t}=f(t)$ at the initial region and $\ln \left(1-F_{t}\right)=f(t)$ dependence at the final region, gives us a good description of all kinetic curve as $C_{t}^{\text {calc. }}=f(t)$. Relationship between experimental and calculated values of DD concentration was represented by the equation:

$C_{t}^{\text {calc. }}=0,49+1,01 C_{t}^{\text {exper. }}\left(r_{\text {corr. }}>0,99\right)$, which confirms the reliability of this approach for the prediction of the purification process with a noticeable deviation at the initial stage $(0,5-1 \mathrm{hr})$. The time to reach low concentrations of DD in the aqueous phase using a sorbent and 
Parameters of DD removal processes from an emulsion (from one normal dose of nutrients) by sorbent and biosorbent based on Nonwoven AN-3 material $\left(C_{\mathrm{o}}=91 \mathrm{mg} / \mathrm{L}, V=0,1 \mathrm{~L}, g=0,4 \mathrm{~g}\right.$, temp: $\left.20-22{ }^{\circ} \mathrm{C}, \mathrm{pH}_{\text {init. }}=8,6\right)$

\begin{tabular}{|c|c|c|c|c|c|c|c|c|c|}
\hline \multirow[b]{2}{*}{$\mathrm{t}, \mathrm{hr}$} & \multirow[b]{2}{*}{$C_{t}^{\text {sorb }}, \mathrm{mg} / \mathrm{L}$} & \multirow[b]{2}{*}{$C_{t}^{\text {sum }}, \mathrm{mg} / \mathrm{L}$} & \multirow[b]{2}{*}{$F_{t}^{\text {sorb. }}$} & \multirow[b]{2}{*}{$F_{t}^{\text {sum }}$} & \multicolumn{2}{|c|}{ contribution } & \multicolumn{3}{|c|}{$q_{t}, \mathrm{mg} / \mathrm{g}$} \\
\hline & & & & & $\begin{array}{l}\text { sorption } \\
\Delta_{\text {sorp. }}\end{array}$ & $\begin{array}{l}\text { destruction, } \\
\Delta_{\text {destr. }}\end{array}$ & sum & sorption & destruction \\
\hline 0,5 & 58 & 44 & 0,36 & 0,52 & 0,70 & 0,30 & 11,75 & 8,20 & 3,51 \\
\hline 1 & 48 & 38 & 0,47 & 0,58 & 0,81 & 0,19 & 13,25 & 10,70 & 2,51 \\
\hline 2 & 37 & 21 & 0,6 & 0,77 & 0,77 & 0,23 & 17,5 & 13,50 & 4,04 \\
\hline 4 & 34 & 16 & 0,63 & 0,82 & 0,76 & 0,24 & 18,75 & 14,20 & 4,52 \\
\hline 6 & 27 & 15 & 0,70 & 0,84 & 0,84 & 0,16 & 19,00 & 16,00 & 5,04 \\
\hline 24 & 25 & 8 & 0,73 & 0,91 & 0,79 & 0,21 & 20,75 & 16,50 & 4,27 \\
\hline
\end{tabular}

biosorbent based on $\mathrm{AN}-3$ can be predicted by using logarithmic dependence specifically for the final region:

$$
\begin{aligned}
& \ln \left(1-F_{t}^{\text {sum }}\right)=-1,55-0,040 t \\
& \left(r_{\text {corr. }}=0,99\right)-\text { for biosorbent } \\
& \ln \left(1-F_{t}^{\text {sorb. }}\right)=-0,97-0,015 t \\
& \left(r_{\text {corr. }}=0,96\right)-\text { for pure sorbent. }
\end{aligned}
$$

When using pure sorption based on $\mathrm{AH}-3$, the concentration of DD in aqueous phase reached about 2,0 $\mathrm{mg} / \mathrm{L}$ in 8 days, while using a biosorbent based on $\mathrm{AH}-3$ the concentration of DD reached 10 times less $(0,2 \mathrm{mg} / \mathrm{L})$ concentration in 5 days and in 8 days the DD concentration was less than $\mathrm{MPC}_{\mathrm{w}}-0,02 \mathrm{mg} / \mathrm{L}$. It was shown that, $\mathrm{AH}-3$ biosorbent provides high efficiency for DD removal from aqueous phase, compared to a similar sorbent without immobilized microorganisms. Contribution of biodegradation in water purification process is at average $22 \%$, although it should be noted that the contribution of the sorption of DD from an emulsion for Nonwoven material AN-3 (78\%) is slightly higher than for Nonwoven material PP (65\%). For the normal performance of immobilized microorganisms in the porous structure of the sorbents, it was necessary to establish limiting factors for the effective functioning of biosystem, determine the optimum activity conditions, quantitatively estimate the activating factors and calculate activation constants. As activator we considered a high dose of mineral solution added to aqueous emulsion of $\mathrm{DD}$, thus, changing the activity of the substrate solution.

For example, biosorbent based on vermiculite "Versoil" demonstrates the effectiveness of the biosystem and viability of immobilized cells of microorganisms under the limiting condition of substrate biochemical oxidation of concentration of $100 \mathrm{mg} / \mathrm{L}$. Table 3 summarizes the main parameters of kinetic equations in logarithmic coordinates $\ln \left(1-F_{t}^{\text {sum }}\right)=A-B t$, obtained for this block.

It is experimentally shown that parameters of the kinetic equations at constant initial concentration of DD in

\begin{tabular}{|c|c|c|c|c|c|c|}
\hline Parameters & I cycle & II cycle & III cycle & $X_{\text {average }}$ & SDs (s) & $\begin{array}{l}\delta \text {, отн. } \\
\%\end{array}$ \\
\hline ConstantA & $-1,840$ & $-1,55$ & $-1,55$ & $-1,65$ & 0,17 & 10,3 \\
\hline ConstantB & 0,019 & 0,022 & 0,019 & 0,020 & 0,002 & 8,1 \\
\hline $\mathrm{R}_{\text {corr. }}$ & $>0,999$ & 0,991 & 0,990 & 0,993 & 0,006 & 0,6 \\
\hline
\end{tabular}
emulsion $\left(\mathrm{C}_{0}=100 \mathrm{mg} / \mathrm{L}\right)$ remains practically unchanged.
* - with one normal dose of mineral.

The obtained data confirmed that, the significant differences of DD removal efficiency from cycle to cycle were not observed and the activity of immobilized microorganism remained unchanged over 3 cycles. The general equation of dependence for 3 cycles is as the following:

$$
C_{t}^{\text {calc. }}=0,26+1,01 C_{t}^{\text {exper. }}\left(r_{\text {corr. }}=0,99\right) \text {. }
$$

The equation has a high correlation coefficient and minimum values of maximum error, which confirms the adequacy of the obtained results and the validity of this approach in forecasting the investigated process. Table 4 shows the predicted calculated values of time ( $t$, days) required to achieve the desired residual concentrations of $\mathrm{DD}\left(C_{\mathrm{t}}^{\text {resid }}\right)$. This required time ranged from 3 to 15,7 days depending on the desired residual concentrations $C_{t}^{\text {resid }}$ of PHCs in an aqueous phase, and for different equations, the error values $(\delta)$ were not greater than 5,6 rel. \%, which is acceptable for practical purposes.

The effect of initial concentration of DD on the removal process was observed at the initial concentration of 50, 100 and $200 \mathrm{mg} / \mathrm{L}$ (Fig. 3). $C_{t}^{\text {sum }}=\mathrm{f}(\mathrm{t})$ dependence show that at the initial stage, the efficiency of DD removal from the aqueous phase increases with the increase of initial concentration. At the same time at the final stage, in the region of low substrate concentration $\left(C_{t}\right.$ less than 6-10 $\mathrm{mg} / \mathrm{L}$ ), the dependence was described by general equation for all concentrations: 
Time required to reach $\mathrm{C}_{\mathrm{t}}$ resid of $\mathrm{PHCs}$ in an aqueous phase using biosorbent "Versoil"

\begin{tabular}{llll}
\hline$C_{t}^{\text {resid. }}, \mathrm{mg} / \mathrm{L}$ & $\mathrm{t}$, days & SDs & $\delta$, rel. \% \\
\hline 10,0 & 1,3 & 0,3 & 19,4 \\
1,0 & 6,1 & 0,3 & 5,6 \\
0,05 & 12,3 & 0,3 & 5,5 \\
0,01 & 15,7 & 0,7 & 5,6 \\
\hline
\end{tabular}

$$
C_{t}^{\text {calc. }}=\mathrm{C}_{0} \exp \left(-0,55-0,012 C_{0}-0,02 t\right) .
$$

The time required for achievement of $\mathrm{MPC}_{\mathrm{w}}$, that was calculated using the corresponding equation for a biosorbent "Versoil", was approximately 12 days.

Table 5 shows the values of $V_{\text {sp. }}$ calculated for biosorbents based on Nonwoven materials of polypropylene fibers PP (neutral) and acrylonitrile fibers AN-3 (containing in their structure the groups of primary and secondary amines). For comparison, the biosorbent based on natural mineral group of the brand "Versoil" was examined.

In table 5, the kinetic data of biodegradation rate by biosorbents based on PP and AH-3 are almost the same. The processes of biodegradation depend on the affinity of enzymes to the substrate (in our case on petroleum hydrocarbons and potential competitors, e.g. heavy metal ions or inhibitors of organic nature). It should be noted that for the biocatalytic system immobilized on the sorbent, inhibitory effect on real wastewater of carwash was practically absent.

Values of specific rate of bio-destruction of $V_{\text {sp. }}$ for Nonwoven materials with the immobilized cells and a biosorbent with the cells on based on "Versoil"

\begin{tabular}{|c|c|c|c|}
\hline \multirow[b]{2}{*}{$\mathrm{t}, \mathrm{hr}$} & \multicolumn{3}{|c|}{$V_{s p,}(\mathbf{m g} / \mathbf{g}) \cdot \mathbf{h r}^{-1}$} \\
\hline & $\begin{array}{l}\text { PP } \\
\text { (2Ps, Rhod)* }\end{array}$ & $\begin{array}{l}\mathrm{AH}-3 \\
(2 \mathrm{Ps}, \text { Rhod) }\end{array}$ & $\begin{array}{l}\text { "Versoil» } \\
\left(2 \text { Ps,Rhod) }{ }^{* * *}\right.\end{array}$ \\
\hline $\mathrm{DD} \mathrm{C}_{0}, \mathrm{mg} / \mathrm{L}$ & 89 & 91 & 100 \\
\hline 0,5 & 27,5 & 23,5 & Lag-phase \\
\hline 1 & 14,5 & 13,3 & Lag-phase \\
\hline 2 & 7,8 & 8,8 & Lag-phase \\
\hline 4 & 4,6 & 4,7 & Lag-phase \\
\hline 6 & 3,1 & 3,2 & Lag-phase \\
\hline 24 & 0,8 & 0,9 & 1,07 \\
\hline 48 & - & - & 0,56 \\
\hline 72 & - & - & 0,38 \\
\hline 96 & - & - & 0,29 \\
\hline 120 & - & - & 0,23 \\
\hline
\end{tabular}

* - weight of PP = 0,4 g; temp.: $20-22^{\circ} \mathrm{C}$; pHinti. = 8,9;

${ }^{* *}$ - weight of AN-3 $=0,4 \mathrm{~g}$; temp.: $20-22^{\circ} \mathrm{C}$; pHinti. $=8,6$;

${ }^{* * *}$ - weight of vermiculite $=0,35 \mathrm{~g}$; temp.: $20-22^{\circ} \mathrm{C}$.

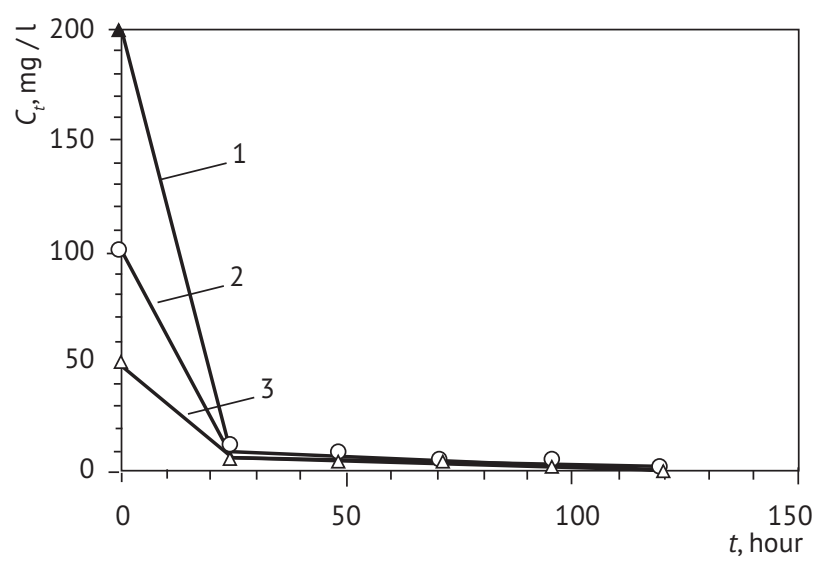

Fig. 3. The change in concentration of DD in aqueous phase with time for biosorbent "Versoil" for three different initial concentrations $\left(V=0,1 \mathrm{~L}, g=0,35 \mathrm{~g}\right.$, Temp.: $\left.20-22^{\circ} \mathrm{C}\right)$ :

$1-C_{0}=200 \mathrm{mg} / \mathrm{L} ; 2-C_{0}=100 \mathrm{mg} / \mathrm{L} ; 3-C_{0}=50 \mathrm{mg} / \mathrm{L}$.

For the period up to 24 hours, a biosorbent "Versoil" reflects a lag-phase which is characterized by the cells adaptation to the new conditions as well as high oxidation activity, when there is a rapid decrease in the concentration of DD in the emulsion. In microbiology it is assumed that the initial phase of the growth of microorganisms characterized by a delay of reproduction and only a small number of microorganisms were divided. Moreover, the higher concentrations of DD in the emulsion lead to higher specific rate of biodegradation (Fig. 4). For comparison of the performance efficiency of immobilized cells, Fig. 4 shows the dependence of the change in the concentration of DD in the emulsion by biosorbent based on AN-3 with time after using normal and double dose of mineral solution (Table 6).

The quantity of immobilized cells (2Ps, Rhod.) on biosorbent AN-3 was 25-28 mg of dry cells per $1 \mathrm{~g}$ of support

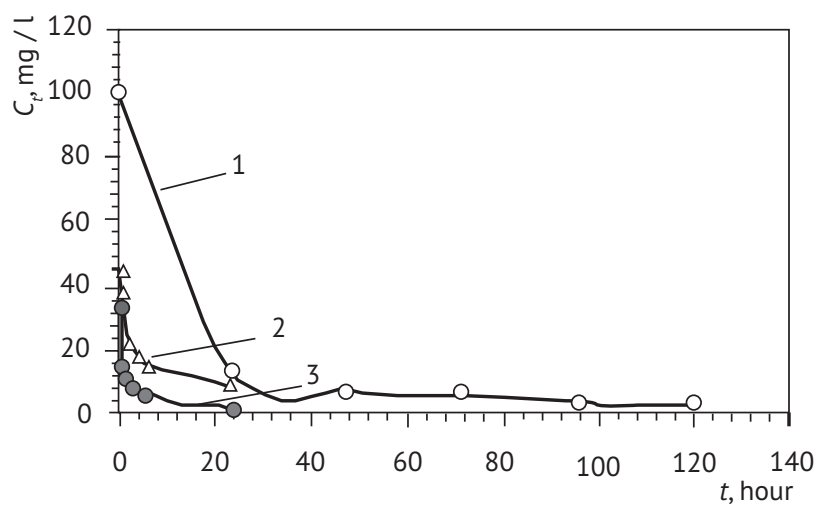

Fig. 4. Changes of DD concentration in the emulsion over time with normal dose:

1 - biosorbent "Versoil", Activation - 1 normal dose; 2 - biosorbent AN-3, Activation - 1 normal dose; 3 - biosorbent AN-3, Activation 2 normal doses. 
Comparative assessment of functioning of cells immobilized on Nonwoven material (AN-3) and "Versoil"

\begin{tabular}{|c|c|c|c|c|c|c|c|c|}
\hline \multirow{3}{*}{$\begin{array}{l}\text { Basis for cell } \\
\text { immobilization } \\
\text { (2Ps,Rhod) }\end{array}$} & \multirow{3}{*}{$\begin{array}{l}\text { Dose of } \\
\text { activation } \\
\text { solution }\end{array}$} & \multirow{3}{*}{$\begin{array}{l}\text { Lag- } \\
\text { time, hr }\end{array}$} & \multicolumn{4}{|c|}{$\begin{array}{l}\text { Concentration of DD in the emulsion after contacting time } 24 \mathrm{hr} \\
\text { with sorbent }\left(C_{t}^{\text {sorp. }}\right) \text { and biosorbent }\left(C_{t}^{\text {sum. }}\right)\end{array}$} & \multirow{2}{*}{\multicolumn{2}{|c|}{$\begin{array}{l}\text { Contribution of sorption and } \\
\text { biodestruction processes }(\%) \\
\text { over } 24 \mathrm{hr}\end{array}$}} \\
\hline & & & \multirow{2}{*}{$\begin{array}{l}\begin{array}{l}\text { Sorbent } \\
\text { without cell }\end{array} \\
C_{t}^{\text {sorp. }}, \mathrm{mg} / \mathrm{L} \\
\end{array}$} & \multicolumn{3}{|c|}{ Sorbent with immobilized cells } & & \\
\hline & & & & $C_{0}, \mathrm{mg} / \mathrm{L}$ & $C_{t}^{\text {sum }}, \mathrm{mg} / \mathrm{L}$ & $C_{t}^{\text {destr. }}, \mathrm{mg} / \mathrm{L}$ & sorption & biodestruction \\
\hline «Versoil» & 1 & 24 & 33,7 & 100 & 12,0 & 54,3 & 38,3 & 61,7 \\
\hline AN-3 & 1 & 5,5 & 25 & 91 & 8,0 & 58 & 30,0 & 70,0 \\
\hline $\mathrm{AN}-3$ & 2 & 5,5 & 25 & 91 & 1,0 & 65 & 28 & 72,0 \\
\hline
\end{tabular}

material at a normal dose of mineral medium, while at a double dose was $42-51 \mathrm{mg} / \mathrm{g}$ after 24 hours contacting time.

Fig. 5 shows photographs obtained by scanning electron microscopy for pure nonwoven material and nonwoven with immobilized cells based on single and double normal dose of nutrients. As can be seen, a double dose of nutrients provides a significant amount of immobilized cells on the fibers of the nonwoven material, which is in good agreement with the results of gravimetric analysis and efficient functioning of the biosorbent, shown in Fig. 4.

A duplication of the activation solution dose provided a significant reduction in the residual concentration of DD in the emulsion. The effect of heavy metal ions and organic inhibitors on the activity of cells was not detected even in the waste water of carwash. According to this theory and experimental data, the substratum is exposed to active chemical transformation, especially intensively at high concentrations of substrate, i.e. active center ( $\mathrm{SH}-$ group) is not blocked and the system works as an effective biooxidation catalyst (Fig. 4).

According to the data provided in Table 6, we concluded that the lowest residual concentration of DD in the emulsion can be achieved by using biosorbent AN-3 (2Ps, Rhod) with single and double doses of the activation solution. DD residual concentration after 24 hours of contact of the emulsion with a sorbent "Versoil" does not satisfy the requirements of quality of natural water for fishing.
Higher contribution of biodegradation (\%) in the DD removal process was characteristic for sorbent based on Nonwoven material with a small size of sorbent material (fiber 3-5 mm), a large fraction of free cross-section layer $(\alpha=0,8-0,9)$, compactness, high surface area, low hydrodynamic resistance.

\section{Conclusion}

A comparative study of the effectiveness of the processes of sorption and bio-oxidation of dodecane emulsion by sorbents and biosorbents with immobilized microorganisms on the same carriers was conducted. Nonwoven materials have been investigated based on polypropylene (neutral) and acrylonitrile fibers (containing in their structure groups of primary and secondary amines). For comparison, biosorbent based on natural mineral (vermiculite) have been investigated.

Biodegradation rate, effectiveness of sorption process, as well as changes of biocatalytic activity at repeating use of the given biosystemwere examined. Biosystem based on acrylonitrile Nonwoven material demonstrated high effectiveness, allowing the reduction of DD concentration to a maximum permissible concentration within 8 days.

It is obvious from this study; it is possible to create an artificial biosystem with an effective and self-regeneration characteristics, which concentrate and biodegrade PHCs, based on polymer and inorganic materials.

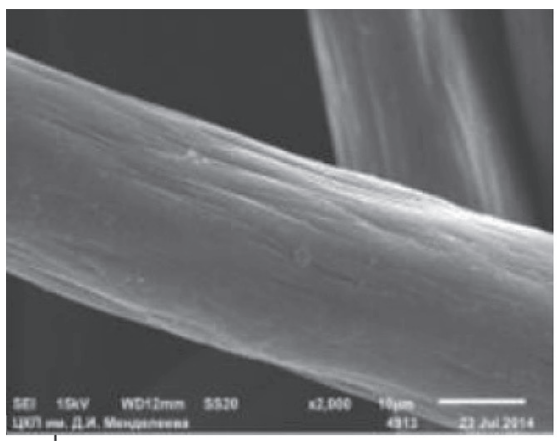

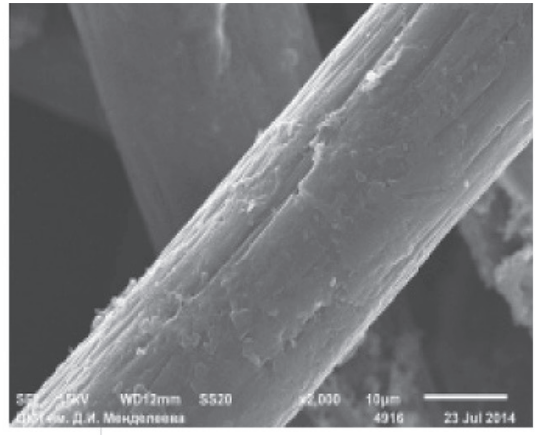

b

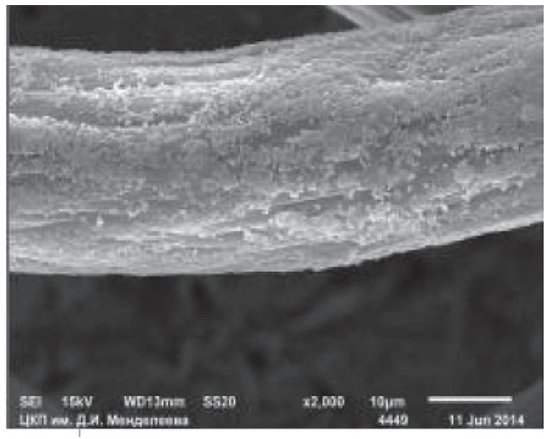

C

Fig. 5 Scanning electron microscopic images of nonwoven materials (a) pure AN-3, (b) AN-3 with immobilized cell (one normal dose), and AN-3 with immobilized cells (double normal dose). 
The Part of the research leading to these results hasreceived funding from Russian Ministry of Education

\section{REFERENCES}

1. Belfanz J \&Rehm HJ (1991) Biodegradation of 4-chlorophenol by adsorptive immobilized Alcaligenes sp. A 7-2 in soil. Appl. Microbiol. Biotechnol. 35: 662-668

2. Bettemann H \&Rehm HJ (1984) Degradation of phenol bypolymer entrapped microorganisms. Appl. Microbiol. Biotechnol.20: 285-290

3. Boyd G. E., Adamson A. W., Meers L. S. The exchange adsorption of ions from aqueus solutions by organic zeolites. II Kinetics. - J. Amer. Chem. Soc., 1947, vol. 69, p. 2836-2848.

4. Cherkasova T.A., Koshchug VA, Leykin Y.A., 1999. Studying of enzymatic hydrolysis of the urea, immobilized urease. Applied biochemistry and microbiology, vol. 35 (2): 155-159, (in Russian).

5. Dixon, M., Webb, E., 1982. Enzymes: translation from D.Sc. chem. Sciences L. M. Ginadman and Ph.D. of chem. Sciences M. I. Levyant / under the editorship of Dr. chem. Sciences prof. V. K. Antonov and academician A.E. Brownshtein, vol. 2, 806 p, (in Russian).

6. Foght JM, Semple K, Gauthier C, Wetlake DWS, Blenkinsopp S, Wang Z, Fingas M (1999). Effect of nitrogen source on biodegradation of crude oil by a defined bacterial consortium incubated under cold, marine conditions. Environ. Technol. 20:839-849.

7. Gerdes B, Brinkmeyer R, Dieckmann G, and Helmke E. 2005. Influence of crude oil on changes of bacterial communities in Artic sea-ice. FEMS Microbiology Ecology, 53:129-139.

8. Ghazali F M, Abdul Rahman R N Z, Salleh A, Basri M. (2004).Biodegradation of hydrocarbons in soil by microbial consortium. International Biodeterioration\& Biodegradation, 54: 61 - 67, (DOI:10.1016/j.ibiod.2004.02.002).

9. Kochar GS \&Kahlon RS (1995) Degradation of 2,4-dichloro phenoxy acetic acid by immobilized cells of Pseudomonas putida. J. Gen. Appl. Microbiol. 41: 367-370

10. Komukai-Nakamura SK, Yamauchi TH, Inomata Y, Venkateswaran K, Yamamoto THS, Harayama S (1996). Construction of bacterial consortia that degrade Arabian light crude oil. J. Ferment. Bioeng. 82: 570-574.

11. Lee ST, Rhee SK \& Lee GM (1994) Biodegradation of pyridine by freely suspended and immobilized Pimelobacter sp. Appl. Microbiol. Biotechnol. 41: 652-657

12. Leykin Y.A., Cherkasova T.A., Smagina N.A., 2008. The self-regenerated sorbents for purification of water from petroleum hydrocarbons. Sorption and chromatographic processes, vol. 8 (4): 585-599, (in Russian).

13. Leykin Y.A., Cherkasova T.A., Smagina N.A., 2009. Vermiculite sorbent for purification of water from petroleum hydrocarbons. Sorption and chromatographic processes, vol. 9 (1): 104-117 (in Russian). and Science of the Russian Federation through the grant agreement №5.2598.2014/K.

14. Li Q., Kang C., Zhang C., (2005). Waste water produced from an oilfield and continuous treatment with an oildegrading bacterium, Process Biochem., 40: 873-877.

15. Malik ZA, Ahmed S (2012). Degradation of petroleum hydrocarbons by oil field isolated bacterial consortium. Afr. J. Biotechnol. 11(3): 650-658.

16. Menke B \&Rehm HJ (1992). Degradation of mixtures of monochlorophenols and phenols as substates for free and immobilized cells of Alcaligenes sp. A 7-2 in soil. Appl. Microbiol. Biotechnol., 37: 655-661

17. Miziev Magomed A., Kugotova M.M., Cherkasova T.A. (2016). Polymer indicators for the rapid control of the environment. Education and science for sustainable development. Scientific practical conference and school of young scientists: conference materials:. $3 \mathrm{~h}-$ M.: MUCTR. DI. Mendeleev. Ch.1. ISBN 978-5-7237-1384-0: 22-26, (in Russian).

18. O’Reilly KT \& Crawford RL (1989) Degradation of pentachlorophenol by polyurethane-immobilized Flavobacterium cells. Appl. Environ. Microbiol., 55: 2115-2118

19. Ojo OA (2006). Petroleum Hydrocarbon Utilization by Native Bacterial Population from a Wastewater Canal Southwest Nigeria. Afr. J. biotechnol. 5(4):333-337.

20. Oteyza de TG, Grimalt JO, Lliros M, and Esteve I. (2006). Microcosm experiments of oil degradation by microbial mats. Science of the Total Environment. V. 357 (1-3): 12-24, (DOI: 10.1016/j.scitotenv.2005.04.039).

21. Sahasrabudhe SR, Modi AJ \&Modi VV (1988). Dehalogenation of 3 chlorobenzoate by immobilized Pseudomonas B-13 cells. Biotechnol. Bioeng. 31: 889-893

22. Schatzberg P. U.S. Coast Guard Report No. 724110.1/2/1. Technical Report, U.S. Coast Guard Headquarters, Washington, DC, 1971.

23. Sun Y, Chen Z, Xu S, and Cai P. (2005). Stable carbon and hydrocarbon isotopic fractionation of individual n-alkanes accompanying biodegradation: evidence from a group of progressively biodegraded oils. Organic Geochemistry, 36: 225-238.

24. Trindade PVO, Sobral LG, Rizzo ACL, Leite SGF, and Soriano AU. (2005). Bioremediation of a weathered and recently oil-contaminated soils from Brazil: a comparison study. Chemosphere, 58: 515-522.

25. Walkup P. C.; Polentz L. M.; Smith J. D.; and Peterson P. L. (1969). Study of equipment and methods for removing oil from harbor waters. In Joint Conf. on Prevention and Control of Oils, pages 237-248.

26. Westmeier F \&Rehm HJ (1985). Biodegradation of 4-chlorophenol by entrapped Alcaligenes sp. A 7-2. Appl. Microbiol. Biotechnol. 22: 301-305 
27. Westmeier F \&Rehm HJ (1987). Biodegradation of 4-chlorophenol in municipal waste water by absorptive immobilized Alcaligenes sp. A 7-2. Appl. Microbiol. Biotechnol. 26: 78-83.
28. Znamensky Y. P., 1993. Good approximating expression for the solution of a diffusion equation in a sphere. J. Phys. Chemistry, vol. 67 (9): 1924-1925, (In Russian).

\section{Твердофазные биосорбенты для очистки воды от нефтяных углеводо- родов}

Ю.А. Лейкин, д-р хим. наук, профессор, Российский химико-технологический университет имени Д.И. Менделеева. Т.А. Черкасова, канд хим наук, ст.науч. сотр., ведущий науч. сотр. Российский химико-технологический университет имени Д.И. Менделеева

Мохамед Абд-Элнаби Али-Элдиин (М. A. Aly-Eldeen) исследователь, Национальный институт океанографии, Александрия, Египет.

М.А. Мизиев, аспирант, Российский химико-технологический университет имени Д.И. Менделеева

На модельном растворе додекана исследованы сорбенты с иммобилизованными клетками микроорганизмов рода Pseudomonas (K-5-25, K-2) и Rhodococcus (EriA. 2-4M). Рассмотрены сорбенты на основе нетканых материалов из полипропиленового волокна (нейтрального) и из акрилонитрильного волокна (содержащего в своей структуре группы первичного и вторичного аминов), а также на основе вермикулита, природного минерала из группы гидрослюд слоистого строения. Проведена оценка эффективности сорбционного и биокаталитического вкладов для изучения степени очистки воды. Такие саморегенерирующиеся системы, сочетающие физико-химическое и биологическое удаление нефтяных углеводородов из растворов с малыми и следовыми концентрациями, могут работать в динамическом режиме. При этом сорбент выполняет одну из важнейших функций биосистемы, обеспечивая доставку и накопление нефтяных компонентов из жидкой фазы, а иммобилизованные клетки осуществляют саморегенерацию биосорбента. Анализ сравнительной эффективности этих процессов с использованием кинетического анализа результатов, полученных на твердофазном сорбенте с иммобилизованными клетками и на исходном сорбенте без клеток, позволил определить степень физико-химического удаления додекана из водной эмульсии и степень его биодеградации, как в жидкой, так и в твердой фазе сорбционного материала. Наиболее эффективным оказался биосорбент на основе акрилонитрильного нетканого материала, позволивщий уменьшить концентрацию додекана в системе до уровня ПДКрыб.хоз. в течение восьми дней.

Ключевые слова: сорбция, биодеструкция, иммобилизованные клетки микроорганизмов, биосистемы, кинетика.

\section{Россия не присоединилась к регулированию выбросов парниковых газов при авиаперевозках}

Экспериментальный этап схемы регулирования выбросов парниковых газов (ЕТС) в авиаперевозках был одобрен Международной организацией гражданской авиации (ICAO). Россия считает, что покупка квот на ЕТС превратит авиацию в источник возврата инвестиций для экологических проектов в других отраслях, вытеснит с рынка авиакомпании из развивающихся стран и снизит безопасность полетов. Поэтому Москва вместе с Дели и Пекином предложили альтернативу - единый экологический сбор с каждой тонны топлива.

Ряд стран - участниц ICAО предварительно одобрили механизм, ограничивающий объем выбросов углекислого газа самолетами. Речь идет о так называемых «Глобальных рыночных мерах в гражданской авиации» (GMBM). По схеме, одобренной 63 членами ICAO, авиакомпаниям, выполняющим международные рейсы и превысившим бесплатную норму выбросов парнико- вых газов (ЕТС), придется покупать «квоты на выбросы» на специальной бирже. Средства пойдут на природоохранные проекты (поддержку зеленой энергетики, лесонасаждение и т. д.).

Представители России поясняют, что даже небольшая дополнительная финансовая нагрузка ограничит возможности развития для большинства авиакомпаний из развивающихся стран и вытеснит их с рынка международных перевозок. Без финансирования придется продлевать ресурс устаревшей техники, что увеличит эмиссию, негативно отразится на заказах новых самолетов, ухудшит безопасность полетов. По прогнозным оценкам, только за первые 15 лет общие потери авиаотрасли от новой системы составят около \$200 млрд.

Заметно изменить резолюцию ICAO вряд ли получится, но в документ все же будут внесены оговорки, в том числе от России и США. 